\title{
THE EFFECT OF INQUIRY LEARNING AND PEER TEACHING TOWARD STUDENTS' LEARNING OUTCOME OF FOREARM PASS VOLLEY BALL FOR SEVENTH GRADE MALE STUDENTS OF SMPN 17 JAMBI
}

\author{
${ }^{1}$ Palmizal A, ${ }^{2}$ Alek Octadinata \\ Correspondence: University of Jambi, Jambi, Indonesia \\ E-mail:palmizal@unja.ac.id, alek_oktadinata@unja.ac.id
}

\begin{abstract}
Abstrak
Penelitian ini bertujuan untuk pengaruh model pembelajaran inkuri dan dan peer teaching terhadapa peningkatan hasil belajar passng bawah. Rancangan penelitian menggunakan kuasi eksperimen dengan two group preetest posttest design. Populasi dari penelitian ini adalah siswa SMP Negeri 17 Kota Jambi, sampelnya kelas VII. Data dianalisis dengan analisis iju beda mean dengan menggunakan uji-t. Hasil penelitian menunjukkan bahwa terdapat peningkatan hasil belajar passing bawah bola voli. Pada data pree test metode inkuiri diperoleh rata-rata 3,65 poin dan nilai rata-rata pada postest sebesar rata-rata 3,96 poin. Sedangkan pada data pree test model pembelajaran peer tesching diperoleh rata-rata 3,65 poin dan nilai rata-rata pada postest sebesar rata-rata 3,84 poin. Berdasarkan perhitungan uji T Depeden diketahui nilai signifikansi $p$ value sebesar 0,003 dengan nilai ini lebih kecil dari nilai signifikansi $T$ tabel, sedangkan batas penolakan adalah 0, 05, sehingga hipotesis alternatif ( $\mathrm{Ha})$ diterima, maka terdapat pengaruh pembelajaran passing bawah bola voli menggunakan model inkuiri terhadap hasil passing bawah pada siswa putra kelas VII SMP Negeri 17 Kota Jambi. Terdapat pengaruh pembelajaran passing bawah bola voli menggunakañ modet peer teaching terhadap hasit passing bawah pada siswa putra kelas VII SMP Negeri 17 Kota Jambi.
\end{abstract}

\section{Kata Kunci: Model Pembelajaran, Passing Bawah Bolavoli}

\begin{abstract}
This study aimed to influence inquiry learning model and peer teaching towards increasing learning outcomes of forearm pass. The research design used quasiexperimental with two groups pre-test posttest design. The population of this research was students of SMP Negeri 17 Jambi, the sample was the seventh grade. Data were analyzed by analysis of the mean differences using the t-test. The results showed that there was an increase in learning outcomes forearm pass volleyball. In the pre test data, the inquiry method obtained an average of 3.65 points and an average value on the posttest of 3.96 points. Whereas in the pre-test data, the peer test learning model obtained an average of 3.65 points and the average value at the posttest was an average of 3.84 points. Based on the
\end{abstract}

PJKR_

http://jurnal.unimed.ac.id/2012/index.php/jpehr 
Depedent $\mathrm{T}$ calculation, it was known that the significance value of $\mathrm{p}$ value is 0.003 with this value smaller than the significance value of the $\mathrm{T}$ table, while the rejection limit was 0,05 , so that the alternative hypothesis (Ha) was accepted, there was the effect of learning to forearm pass volleyball using the inquiry model on the results of passing under the male students of seventh grade SMP Negeri 17 Jambi. There was an influence of learning to forearm pass volleyball using a peer teaching model to the results of forearm pass in male students of seventh grade SMP Negeri 17 Jambi.

\section{Keywords: Learning Model, Forearm Passing Volleyball}

\section{Introduction}

Fajar (2005) in essence learning is an activity carried out by someone to produce changes in themselves, both in the form of new knowledge and skills as well as in the form of positive attitudes and values. Rifa'i (2009) learning is an important process for changing people's behavior and learning includes everything that someone thinks and does. Success or failure of the implementation of teaching and learning activities can be known after the evaluation activities. Beside that, the evaluation results are also used as input in the preparation and implementation of further programs. Tisnowati (2005) explained that the learning process of a teacher begins with the preparation of teaching programs or lesson plans, then implements the program or implementation of learning and the teacher evaluates or evaluates to determine its success.

The low ability of students because of the factors causing the lack of student interest in attending Physical Education lessons which will ultimately affect the physical education score itself. One of them is the internal factor of the student, where students feel bored or bored with the material taught by the teacher. So it is necessary to hold varied and interesting learning materials that are appropriate to the age characteristics of students in SMP Negeri 17 Jambi. Students need adequate guidance, encouragement, and opportunities to learn and learn the things needed in their lives, Sabaruddin and Santi (2018). For this reason, learning models are needed that can motivate students to be able to move, one of them is by using inquiry learning models and peer teaching.

Human curiosity continues to develop into adulthood using his brain and mind. His knowledge will be meaningful when based on that curiosity. The term inquiry comes from English, namely inquiry which means a question or inquiry. Inquiry learning is a series of learning activities that maximally involve all students' abilities to search and investigate systematically, critically, logically, analytically, so students can formulate their own findings with confidence, Trianto (2013).

Trianto (2013) stated that the inquiry model means a series of learning activities that maximally involve all students' abilities to search and investigate systematically, critically, logically, analytically, so that they can formulate their own findings with confidence. Hamruni (2012) said that inquiry learning is a 
series of learning activities that emphasizes the process of thinking critically and analytically to seek and find answers to a problem in question. The classroom situation with students having heterogeneous interests requires the teacher to use the right model.

Sanjaya (2006), inquiry learning is a series of learning activities that emphasize the process of thinking critically and analytically to look for and find the answers to an issue in question. Inquiry learning is built with the assumption that from birth humans have desire to discover their own knowledge. Curiosity about the state of nature around it is natural since he was born into the world, through the sense of sight, the sense of hearing, and the other senses.

The main purpose of inquiry learning is to help students develop intellectual discipline and thinking skills by giving questions and getting answers on the basis of their curiosity, Sanjaya (2006). Amin (2007) inquiry as a learning strategy has several advantages such as encouraging students to think and work on their own initiative, creating an academic atmosphere that supports studentcentered learning, helping students develop positive self-concepts, increasing expectations so students develop ideas to complete assignments in its own way, developing individual talents optimally, preventing students from learning how to memorize.

Inquiry is one of the learning models that plays an important role in constructing constructivist learning paradigms that emphasize the activeness of students by learning through inquiry students will be involved in the process of organizing their knowledge structures through combining previously owned concepts with newly acquired ideas, in inquiry students are motivated to be directly involved or play an active role physically and mentally in learning activities. The classroom environment in which students are actively involved and the teacher acts as a learning facilitator is very helpful in achieving learning goals, Sanjaya (2006).

One learning model that is no less interesting and fun is the peer teaching model (peer tutorial). This is intended to facilitate the needs of students and avoid the boredom experienced by students because of monotonous learning in class. The peer teaching model (peer tutorial) is one model to encourage meaningful learning that involves students teaching and learning from one another. Soeprodjo (2008) stated that the peer teaching model (peer tutor) is a model that is done by way of empowering the ability of students who have high absorption, these students teach material or practice to their friends who do not understand. Peer teaching (peer tutoring) can improve student learning outcomes, learning resources not only from teachers but from classmates whose grades are higher.

Having good mastery of basic volleyball techniques in students requires ongoing training that starts early. If the basic techniques are well owned, you will be able to play volleyball well too. Knowledge of basic techniques and advanced techniques is required to be able to play volleyball effectively. The basic techniques for playing volleyball include passing, service, smash and block. In order for students to be able to pass under it properly and correctly, systematic and 
programmed learning must be done. A teacher must be able to choose an exercise model that is easy for students to learn and understand.

Advantages and disadvantages of Peer Teaching there are several advantages and disadvantages by using peer tutors, Ginting (2010) as follows: a) There are times when the results are better for some students who have feelings of fear or are reluctant to their teacher; b) For tutors the tutoring job will be able to strengthen the concepts being discussed. c) For tutors is an opportunity to train yourself to take responsibility in carrying out a task and practice patience. d) Strengthening relationships between students so as to strengthen social feelings.

Beside the advantages, the drawbacks of the Ginting peer model (2010) are as follows: are as follows. a) Students who are assisted often learn less seriously because only dealing with their own friends so the results are less satisfying, b) There are some students who feel shy or reluctant to ask because they fear that their weaknesses are known by their friends, c) In certain classes this tutoring job is difficult implemented because of gender differences between tutors and students who are given improvement programs, d) For teachers it is difficult to determine a peer tutor because not all smart students can teach it back to their peers.

Passing learning in this study is only the implementation of forearmpassing learning is a learning process carried out by way of guidance, giving knowledge or passing material and training to students (players) in a programmed learning process to get maximum results in learning the required forearm-passing technique a good model, namely the inquiry learning model and peer teaching. In doing forearm-passing volleyball is inseparable from the implementation of forearm-passing is good and right done by students. Starting from this thought, this research will look for the effect of inquiry learning models on volleyball passing learning outcomes.

\section{Method}

The implementation of this research was carried out at SMP Negeri 17 Jambi. The population of this study was all students of SMP Negeri 17 Jambi. Sampling in this study was cluster random sampling. Research methods to uncover the effect of the inquiry learning model and peer teaching on under passing skills. The method used in this study was a True Experiment research method with the design of two groups Pretest-Posttest Design, Fraenkel (2012). Pretest was conducted to the experimental group and the control group. The division of groups used matching pairing techniques.

Data description and hypothesis testing in this study were processed using descriptive and inferential statistics with the bound sample t test formula. Before the $t$ test analysis was performed, the analysis requirements test was first performed, namely the normality and homogeneity of the data test Variance and the $\mathrm{t}$ test was only used to test the mean differences of samples taken from populations that were normally distributed and homogeneous.

\section{Discussion}


Based on the results of the research, it was known that the description of the frequency distribution of the inquiry method research data in the seventh grade male students of SMP Negeri 17 Kota Jambi was obtained for the pretest research data with the inquiry method with a total of 16 people obtained a value of 58.49 points with an average of 3.65 points and had a standard deviation of 0.70 points. Posttest research data with the inquiry method with the number of testers as many as 16 people obtained a total value of 63.50 points with an average of 3.96 points and has a standard deviation of 0.49 points, whereas for the pretest research data the peer teaching method with the number of testers was 16 people obtained a total score of 58.49 points with an average of 3.65 points and have a standard deviation of 0.74 points.

The research data of peer teaching method posttest with 16 testers was 61.50 points with an average of 3.84 points and had a standard deviation of 0.53 points. The final results of research data about the forearm-passing volleyball by using inquiry method with the number of testers as many as 16 people obtained the number of forearm-passing as many as 661 points with an average of 41.31 points. Research data of forearm-passing volleyball by peer teaching method with the number of testers as many as 16 people obtained the number of forearmpassing as many as 684 points with an average of 42.75 points

Hypothesis testing used the Dependent t-test in order to see the effect of learning to forearm-passing volleyball by using inquiry and peer teaching models toward the results of forearm-passing in seventh grade male students of SMP Negeri 17 Jambi, it was described as follows: Based on the calculation of the results of data analysis, the effect of learning forearm-passing volleyball by using inquiry and peer teaching models toward the results of forearm-passing in seventh grade male students of SMP Negeri 17 Jambi, it was known that the significant value of the results was 0.003 and 0.038 , then the data was tested for the correlation significance by comparing the significance value ( $p$ value) of the standard 0.05 which meant the significance of the results $<p$ value. It was stated that there was an effect of learning to forearm-passing volleyball by using inquiry and peer teaching models on the results of forearm-passing in male students of class VII SMP Negeri 17 Jambi with an alternative hypothesis (Ha) accepted.

In the implementation of the learning process activities Guidance emphasizes the learning process procedures, making students more limited in involving scientific and cognitive ideas that they already have, Harris \& Rooks (2010). In principle, the disclosure of the ideal learning outcome covers all psychological domains that are changed due to experience and learning process, Nasrudin (2004).

\section{Conclusion}

Based on the results of research conducted by researchers using the inquiry and peer teaching models toward the results of forearm-passing, it was concluded as follows: a. Based on the Depedent $\mathrm{T}$ calculation, it was known that the significance value of $\mathrm{p}$ value was 0.003 with this value smaller than the 
significance value of the $\mathrm{T}$ table, while the rejection limit was 0,05 , so that the alternative hypothesis (Ha) was accepted, there was the effect of learning to forearm-passing volleyball by using the inquiry model on the results of forearmpassing the seventh grade male students of SMP Negeri 17 Jambi. b. Based on the calculation of the Depedent $T$ test it was known that the significance value of $p$ value of 0.038 with this value was smaller than the significance value of the $T$ table, while the rejection limit was 0.05 , so that the alternative hypothesis (Ha) was accepted, then there was the effect of learning to forearm-passing volleyball by using a peer model teaching on the results of forearm- passing to the seventh grade male students of SMP Negeri 17 Jambi.

\section{References}

Abdorrakhman Ginting, 2012. Esensi Praktis Belajar \& Pembelajaran (Disiapkan untuk Pendidikan Profesi dan Sertifikasi Guru-Dosen). Bandung: Humaniora Abidin.

Amin, M, 2007. Pembelajaran Berbasis Inkuiri Metode dan Aplikasi. Yogyakarta: Pustaka Belajar.

Fajar, Aprianto, 2005. Proses Belajar Mengajar. Jakarta: PT Bumi Aksara.

Fraenkel, Jack. R., and Norman E. Wallen, 2012. How to Design and Evaluate Research in Education 8th Edition. Boston: McGraw-Hill Higher Education.

Hamruni, 2012. Strategi Pembelajaran. Yogyakarta: Insan Madani.

Harris, C. J., \& Rooks, D. L, 2010. Managing Inquiry-Based Sience: Challenges in Enacting Complex Science Instruction in Elementary and Middle School Classrooms. Journal Science Teacher Education. Volume: 21, Edisi: -: 227-240. DOI 10.1007/s10972-009-9172-5.

Nasrudin, 2004. Dasar-Dasar Penilaian Secara Obyektif. Jakarta: Bina Cipta.

Rifa'i, Ahmad, 2009. Psikologi Pendidikan. Semarang: Universitas Negeri Semarang Press.

Sabaruddin Yunis Bangun, Santi Fitriyani, 2018. Peningkatan hasil belajar guling belakang senam lantai melalui gaya mengajar latihan Pada pelajar SMA. Journal Physical Eduation, Health and Recreation, Volume: 3, Edisi: 1: 111.

Sanjaya, 2006. Strategi Pembelajaran Berorientasi Standar Proses Pendidikan. Bandung: Kencana.

Soeprodjo dkk, 2008. Komparasi Hasil Belajar Dengan Metode Tutor Sebaya Dan

Team Work Learning Dalam Pembelajaran Kimia. Jurnal Inovasi Pendidikan Kimia. Volume: 2, Edisi: 2: 294-298.

Tisnowati, Aini, 2005. Jasmani dan Kesehatan. Jakarta: Universitas Terbuka.

Trianto, Ilham, 2013. Model-Model Pembelajaran Inovatif Berorientasi Konstruktivistik. Jakarta: Prestasi Pustaka. 